\title{
A ZSOLTÁROK KÖNYVE KERESZTÉNY SZEMMEL: DÁVID ÉS A PRÓFÉTAI KENET
}

\author{
GÁBOR ORTUTAY
}

Ortutay, Gábor: Book of Psalms from the Christian Point of View: David and Prophetic Anointing, 2019, Vol. 1, Issue 2, pp. 62 - 66. DOI: 10.17846/CEV.2019.01.2.62-66.

ABSTRACT: My study deals with a definition of the Bible and Book of Psalms as spiritual supernatural books based on theology. These facts are proved by themselves on the other hand by the fulfilled prophecies and revelations in spite of a big time differences and by confirmations of earlier arisened prophecies. Book of Psalms also contains statements which are completed or verified 1000 years later or even today.

KEYWORDS: Bible. Book of Psalms. Spirituality. Holy Spirit.

Tanulmányom első részének a témája: a Biblia mint forrás meghatározása a keresztény teológia alapján. A Biblia és így a Zsoltárok könyve spirituális, vagyis természetfölötti eredetű könyv, amiről egyrészt önmaga tesz bizonyságot, másrészt egyedülálló a tartalmát illetően, hogy a próféciák, kinyilatkoztatások a Biblián belül jókora időkülönbséggel beteljesednek, illetve történetileg visszaigazolja a korábban keletkezett próféciákat. A Zsoltárok könyve szintén tartalmaz ilyen kijelentéseket, amik közel 1000 évvel később, illetve a napjainkban teljesednek be és igazolhatóvá váltak.

A teljes Írás Istentöl ihletett, és hasznos a tanitásra, a feddésre, a megjobbításra, az igazságban való nevelésre, hogy tökéletes legyen az Isten embere, minden jó cselekedetre felkészített. (B/2Timóteus 3:16 - 17) $)^{1}$

Tudván elöször azt, hogy az írásban egy prófétai szó sem támad saját magyarázatból. Mert sohasem ember akaratából származott a prófétai szó; hanem a Szent Lélektöl indittatva szólottak az Istennek szent emberei. (B/2Péter 1:20 - 21)

A fenti idézetben szereplő „ihletett” szó a magyar nyelvben a lehelt kifejezésből ered. ${ }^{2}$ Isten, az Ö beszédét kilehelte (mint ahogy az ember is beszéd közben kilehel), tehát benne van az Ő szelleme, lehelése. A Bibliában a Szellem szó héber megfelelője a „rúah", ami azt jelenti, hogy szél, szellem, lehelet, fuvallat, fújás. A második idézetből kiderül, hogy az Isten szent emberei az Isten Szelleme, vagy lehelete által szóltak, és azután azt lejegyezték, ezért hiteles és igazolható a beszédük.

A következő részben azt a szemléletet, illetve megközelítést szeretném megvilágítani, ami a tanulmányom címében is szerepel, vagyis a „keresztény szemmel” kifejezést. Eredetileg a keresztény szó nem a keresztből ered, hanem a Krisztus szóból, ami azt jelenti: Felkent, vagyis egy bizonyos célra, feladatra, Isten munkájára a Szent Szellem által, Isten természetfölötti ereje által felkent személy. Nem véletlen, hogy a Bibliában a Szent Szellem egyik leggyakoribb jelképe az olaj, a kenet.

... és a tanítványokat elöször Antiókhiában nevezték keresztényeknek. (B/Apcsel. 11:26)

A jegyzetkezelésben előforduló „B“ a Szent Bibliát mint forrást jelöli, melyet a pontos igehely megjelölése követi a zárójelben.

2 Az ihlet szó a MÉSZ szerint ,ihel, ihl”: lehel, lehelni-t jelent (MÉSZ, 1. kötet: 585. o.), Bárczi Géza: Magyar szófejtő szótárában a szó eredete ismeretlen és talán hangutánzó. Forrásmunkaként a Jókai Kódexet említi.

3 Alapjelentései: 1. mozgásban lévő szél, amely maga is mozgásba lendít; 2. lélegzet (vétel). 
Az eredeti görög szövegben: „Khrisztianosz”, vagyis Krisztus-párti, Krisztushoz tartozó. Tehát a keresztény szemmel azt jelenti, hogy tanulmányomban a Zsoltárok könyvét a Szent Szellem által ihletett spirituális könyvként közelítem meg, másrészt szeretnék rávilágítani arra az időtálló, spirituális üzenetre, melyből korunk embere meríthet, ha úgy tetszik, a mai kor számára pragmatikus, hasznos és aktuális tartalomra is. Ezzel párhuzamosan az üzenet hétköznapi applikálhatóságát is érintem.

A Zsoltárok könyve szerkesztésileg, tartalmilag a Biblia közepén helyezkedik el. Úgy is mondhatnánk, hogy a kinyilatkoztatás „szíve”, lényege az imádkozás, dicséret, kommunikáció Istennel, végső soron egy bensőséges, őszinte közösség a Mindenhatóval. A Könyv héber elnevezése: Sepher Tehillim, azaz Dicséretek Könyve (Himnuszok). Görögül: Psalmoi (latinul Psalmus) vagy Psalterion, amelynek jelentése: húros hangszerkíséretű versek. A 150 zsoltárból több mint 100 előtt szerepelnek elöírások, megjelölések, utasítások a zenészeknek, például: „az éneklőmesternek a neginóthra” (negínáh), vagyis pengetős hangszerrel kísért ének, vagy Dávid „siggajonja” (siggájon) vagyis dal, himnusz. Az éneklőmesternek a „seminithre” (semínít), vagyis oktáv, a legalacsonyabb hangfekvés, stb.

Összegezhetjük tehát, hogy a Zsoltárok könyvét kivétel nélkül énekelték. Érdekes még megjegyezni, hogy a júdaizmusban, a rabbinikus hagyomány szerint mind a mai napig énekelve imádkoznak a zsinagógákban, illetve az imaházakban. Az éneklés érzelmileg jobban ki tudja fejezni az emberi szív kiáltását Isten felé. Keletkezési ideje: Kr.e. 1000 - 400.

Szerzőség: A zsoltárok több mint felét Dávid szerezte, azokat is, amiknél nincs jelölve a szerző neve. Mivel Dávid vezette be, felügyelte a zenei szolgálatot az istentiszteleten, a többi zsoltár keletkezésében is a rajta lévő kenet, a dicséret szelleme játszott fő szerepet, és így egységesült, harmonizálódott a könyv.

Salamon zsoltárai (72; 127;), Mózes éneke, a 90. zsoltár is harmonikusan kapcsolódik a könyv tartalmához (ami nyilván később, szerkesztés folytán került bele).

A hangszerek: a dicséretben résztvevő (hegedű, trombita, dobok, cimbalom, értsd kézi nyeles csörgő, harsona, fuvola) hangszerek mellett a két fő húros hangszer, amiket Dávid készíttetett, a hárfa és a lant. Érdekesség: a hárfán 22 húr volt, a héber abc 22 betűjének megfelelően, ami például a dicséret vezetésében játszott szerepet. A vezető a kezdéskor megpengetett egy húrt, és a zenészek hallás után tudták beazonosítani a betűt, illetve az annak megfelelő számot, ami az aktuális következő dalt jelezte. Gyakori hangszer volt a tízhúrú lant vagy líra, amire az alábbi idézet is utal:

Jó dolog dicsérni az Urat, és éneket mondani a te nevednek, oh Felséges!... Tïz húrú hegedüvel és lanttal, hárfán való zengedezéssel. (B/92. Zsolt.2-4)

Dávid életéhez már fiatal korában hozzátartozott, hogy szeretett hárfa kísérettel énekelni az Úrnak, és ez a szoros bensőséges kapcsolata Istennel tette őt mindenben sikeressé, eszessé, kedvessé, amiről a környezete is bizonyságot tett:

És attól a naptól fogva az Úrnak lelke Dávidra szálla, és azután is... (B/1Sámuel 16:13) Akkor felele egy a szolgák közül, és monda: Íme én láttam a Betlehemben lakó Isainak egyik fiát, aki tud hárfázni, aki erös vitéz és hadakozó férfiú, értelmes és szép ember, és az Úr vele van. (B/1Sámuel 16:18)

Dávid tette az istentisztelet szerves részévé a hangszeres kísérettel énekelt dicséreteket, zsoltárokat. Ő jelölte ki a zenei vezetőket, a 24 órás szolgálatuk rendjét. 
Gábor Ortutay

És rendele az Úr ládája elé a leviták közül szolgákat, akik hirdessék, tiszteljék és dicsérjék az Urat, Izrael Istenét. (B/1Krónika 16:4)

Grádicsok éneke.; Nosza, áldjátok az Urat mind, ti szolgái az Úrnak, akik az Úr házában álltok éjjelente! (B/134. Zsolt:1)

Salamon király, Dávid fia pedig még tovább fejlesztette, és értékes hangszereket készíttetett.

És csinála a király az ébenfából oszlopokat az Ưr házába és a király házába, és az éneklőknek hegedüket és lantokat. (B/1Királyok 10:12)

És csinála a király az ébenfából lépcsőket az Ưr házába és a király házába, s citerákat és lantokat az éneklőknek... (B/2Krónika 9:11)

A Zsoltárok könyvét tartalmi szempontból, illetve spirituális értelmezésük szempontjából, a következőképpen lehet csoportosítani:

- tanító (didaktikus), például az 1. zsoltár,

- történelmi, például a 68., 78., 105-106., 107. zsoltárok,

- prófétikusak, például a 22., 45., 110., 2.,

- dicsőítő zsoltárok, példának okáért a 95., 98., 149., 150.,

- gyakorlati, hétköznapi élettel kapcsolatosak a 84., 121. (grádicsok éneke) 73., 37. zsoltárok.

A bibliai zsoltárok hangvételére jellemző a személyesség, közvetlenség, az Úrral járó hívő ember megtapasztalásai, belső élete, hite, reménysége, erőtlenségei, félelmei és egyúttal bizakodása az Úrban. Felölelik az emberi élet minden mozzanatát, és igei ösztönzést nyújtanak minden életszituációban, legyen az öröm, bánat, győzelem, félelem, megerősödés, megfáradás, magány, vágyakozás az Úr után, visszatekintés a múlt eseményeire és előretekintés. Különleges erősítő befolyást gyakorolnak ránk az ellenségek támadásaival szemben. Itt az értelmezésben elsősorban gonosz spirituális erökkel szembeni ellenállásra gondolunk, illetve a gyülölködö, rágalmazó, szidalmazó, befeketítő beszédekkel szembeni küzdelemre. Megdöbbentően sok zsoltár szól az ellenség elleni segélykérésröl, több mint 39 zsoltár, majdnem harmada az összesnek (például: 27. 64., 140.). A Biblia utal arra, hogy a nyelv, a beszéd hatalmában van az élet és a halál, és ki mint szeret élni vele, úgy eszi annak gyümölcsét (Capps 2012). A Zsoltárok Könyve istenfélelemre tanít minket a beszédet illetően, hogy hogyan éljünk vele helyesen, illetve hogyan védekezzünk a gonosz beszédekkel szemben.

Összegezve: a zsoltárok (Zsoltárok könyve) megtanítanak imádkozni az élet minden helyzetében, ezért fontos és aktuális ma is a keresztények számára!

Térjünk most rá a prófétikus zsoltárokra. Mint ahogy már utaltam rá korábban, Dávidon a Krisztus (Messiás, Felkent) szelleme volt, ezért több zsoltár beszél a jövőben megjelenő Messiás személyéről, illetve a Vele kapcsolatos eseményekről, cselekedetekről. Ezt az Újszövetség vissza is igazolja, sőt a Jelenések könyve végén maga a Messiás vállal generikus közösséget Dáviddal:

Én, Jézus küldöttem az én angyalomat, hogy ezekről bizonyságot tegyen nektek a gyülekezetekben. Én vagyok Dávidnak ama gyökere és ága: ama fényes és hajnali csillag. (B/Jelenések 22:16)

És származik egy vesszöszál Isai törzsökéböl, s gyökereiböl egy virágszál nevekedik. Akin az Úrnak lelke megnyugoszik: bölcsességnek és értelemnek lelke, tanácsnak és hatalomnak lelke, az Úr ismeretének és félelmének lelke. (B/Ézsaiás/Izaiás 11:1-2) 
A fenti idézett igeszakasz is arról tesz bizonyságot, hogy a Messiás származásilag Dávid családjába (Isai Dávid apja volt) fog beleszületni a megtestesüléskor. A Biblia az az egyedülálló spirituális könyv, amelyen belül a próféciáknak egy jó része igazolhatóan beteljesedik, ugyanis a Bibliai események, kijelentések illeszkednek a történelem idősíkjába, vagyis történelmi tényeket tartalmaz. Nézzünk néhány, a Messiásra vonatkozó prófétai kijelentéseket a zsoltárokban, amik több mint ezer évvel később, az evangéliumok keletkezésének idejében beteljesedtek:

Mivel a te házadhoz való féltő szeretet emészt engem, a te gyalázóidnak gyalázásai hullanak reám. (B/69. Zsolt:10)

A gyalázat megtörte szívemet és beteggé lettem; várok vala részvétre, de hiába; vigasztalókra, de nem találék. Söt ételemben mérget adnak vala, és szomjúságomban ecettel itatnak vala engem. (B/69. Zsolt:21 - 22)

Én Istenem, én Istenem, miért hagytál el engemet? Távol van megtartatásomtól jajgatásomnak szava. $\left(\mathrm{B} / 22\right.$. Zsolt:2) ${ }^{4}$

Mert ebek vettek körül engem, a gonoszok serege körülfogott; átlyukasztották kezeimet és lábaimat. Megszámlálhatnám minden csontomat, ők pedig csak néznek s bámulnak rám. Megosztoznak ruháimon, és köntösömre sorsot vetnek. (B/ 22. Zsolt:17 - 19)

Azért örül az én szívem és örvendez az én lelkem; testem is biztosságban lakozik. Mert nem hagyod lelkemet a Seolban; nem engeded, hogy a te szented rothadást lásson." (B/16. Zsolt:9-10)

Az utolsó idézet Jézus Krisztus testben való feltámadására utal, illetve a halála után nem indultak be a bomlási folyamatok a testében. Ezt a kijelentést a történelmi tények vissza is igazolták.

Végezetül a zsoltárok éneklésének a gyakorlata az Újszövetség korszakában is tovább élt, sőt a mai napig az egyház istentiszteleti gyakorlatának tartalmi elemévé vált. Erre vonatkozó két példa:

És dicséretet énekelvén, kimenének az olajfák hegyére. (B/Máté 26:30)

Ezek után megtérek és felépitem a Dávidnak leomlott sátorát; és annak omladékait helyreállitom, és ismét felállatom azt: Hogy megkeresse az embereknek többi része az Urat, és a pogányok mindnyájan, akik az én nevemröl neveztetnek. Ezt mondja az Úr, ki mindezeket megcselekszi. (B/Apostolok Cselekedetei 15:16)

\section{SUMMARY}

The Bible claims that life and death is in power of speech and language and the fruit of it depends on the life we live. The Book of Psalms teaches us a fear of God, it shows the right way of speeches and protections from evil speeches. The Book of Psalms teaches us to pray in every situation of our lives, that is why is so important for Christians.

\section{IRODALOM}

Bárczi, Géza, 1994. Magyar szófejtő szótár. Budapest: Trezor Kiadó.

Capps, Charles, 2012. A szó teremtő ereje. Budapest: Patmos records.

Mék I. 1992. - Magyar értelmező kéziszótár I. - red: Juházs, J., Szóke, I., O. Nagy, G., Kowalovszky,

M. Budapest: Akadémiai Kiadó, 585. o.

Eloi Eloi Lámmá Sabakhtání, Jézus arámi nyelven beszélt, és arámul idézte a zsoltárt is. 
Gábor Ortutay

Prince, Derek, 2012. Budapest: A Szellem ajándékai. PATMOS Könyvek.

Szent Biblia, 2012. Budapest: Patmos records (Károli Gáspár fordítása alapján).

\section{ELÉRHETŐSÉG}

Ortutay Gábor

Gyülekezeti Ház

Pápa, Kisfaludy u. 16/B

Magyarország

g.ortutay84@gmail.com 